\title{
A History of Islamic Philosophy, 3d ed.
}

\author{
Majid Fakhry \\ New York: Columbia University Press, 2004. 430 pages.
}

That Majid Fakhry's A History of Islamic Philosophy, first published in 1970, has been brought out in a third revised edition can be of no surprise to the many admirers of this most robust of scholars. Fakhry's scholarship is meticulous, and his style, even when handling the most complex ideas, remains simple and straightforward.

As many of the theological questions raised by Islam's key philosophers, particularly those pertaining to free will, justice, rights, and responsibilities, had political implications, each chapter in this book begins with a historical context. However, Fakhry only allows this context to play a subsidiary role, as a backdrop to the main narrative: the history of ideas. This approach lends itself very well to an examination of the ideas held by both individual philosophers and schools of philosophy. Importantly, Fakhry demonstrates how, during several key Islamic epochs, there was no one dominant system of thought, but rather, contending systems of thought. He takes us through these debates step by step, as in, for example, the first theological controversy on free will and predestination (qadar). It is in the presentation of these debates, more than anywhere else, that we see that while $A$ History of Islamic Philosophy is distinguished from the work of many other grand narrative histories by not being marred by a partisan viewpoint, Fakhry's is by no means a clinically scientific approach.

This book comprises thirteen chapters. It begins with "The Legacy of Greece, Alexandria, and the Orient," covers the watershed periods in the 
growth of Islamic philosophy, and includes a chapter on "The Interaction of Philosophy and Dogma" as well as one on "The Rise and Development of Islamic Mysticism." It concludes with an analysis of modernist and contemporary trends.

Fakhry opens with an account of the last years of the Arab conquest of the Near East and the ensuing problems of administering an empire. He begins his story of Islamic philosophy by describing how, by the end of the seventh century, Arabic came to replace Persian and Greek as the state prescribed language. This is a significant shift, for with a change of language comes a change of sensibility. His handling of the Greek material is admirable, particularly as he analyzes the different strands of Platonism and Aristotleanism that began to penetrate Islamic thinking. He is less interested in how this occurred - assuming, no doubt, that this process is familiar to most audiences - than in focusing on the ideas themselves and the intersection between these ideas and the Islamic ideas of that period.

In the second chapter, "Early Political and Religious Tensions," the contest for the caliphate is presented less as a political battle for individual power than a contest between two opposing ideas of power. As this chapter moves on to examine the rise of kalam (theology), Fakhry presents a cogent summary of the Mu' tazilite creed. He then analyzes the position taken by the $\mathrm{Mu}$ tazilah and other rationalizing groups and traditional thinkers on key theological issues regarding God's nature, human beings' nature, and the act of creation. He notes that the "two attributes over which the fiercest controversy raged in theological and philosophical circles were [free] will and speech" (p. 62). These questions would remain important for the following generation of thinkers, as Fakhry shows in the next chapter, which deals with the works of al-Kindi, Ibn al-Rawandi, and al-Razi.

As a "champion of the introduction of Greek and Indian writings into the Muslim world" (p. 67) and a greatly innovative thinker himself, al-Kindi was, as Fakhry demonstrates, Islam's first systematic philosophical writer. Fakhry's reading of al-Kindi (close to thirty pages) is thorough and covers such subjects as al-Kindi's argument of why God is not a bearer of accidents and why the quest for truth can never be reckoned as blasphemous. Fakhry also outlines al-Kindi's development of Aristotle's principles of motion. This chapter and the next, which examines the work of al-Farabi and Ibn Sina, are among the book's strongest.

If there is one chapter in which Fakhry foregoes his objectivity, it is chapter 8: "The Rise and Development of Islamic Mysticism (Sufism)." Perhaps this is why it is the book's weakest chapter. Mysticism, he argues, 
runs counter to many Islamic teachings, for "The Muslim believer [here counterpoised to the mystic] is called upon to accept this world of transient existence (dar al-fana')" (p. 241). To provide a broad overview of the development of Sufism proves difficult on the following two counts: unlike some of the other movements discussed in earlier chapters of this book, Sufism has had a very long existence (and although the form of transmitting its kalam and the long line of creativity associated with its name have changed, it continues to be practiced) and has developed distinctly in different parts of the Muslim world.

The concluding chapters on modernist and contemporary trends bring us up to the present. In the modern period, the source of Islamic inquiry was the same as it was in earlier periods: the Qu'ran. Additionally, the essential questions regarding necessity, free will, and destiny continued unchanged. The framework upon which these questions were hung, however, was markedly different. In this we see, perhaps, the influence of both the Muslim world's contact with the post-Enlightenment West as well as the changing nature of the body politic in Muslim countries. Of the Afghani modernist thinker, Jamal al-Din al-Afghani, Fakhry says: "He reduces religion to a rationalist system of beliefs, shorn of any supernatural content" ( $p$. 349). This is a position to which the Indian (and later, Pakistani) philosopher Muhammed Iqbal did not accede, for: "Iqbal's concept of religion is that of a complex, partly rational, partly ethical, and partly spiritual experience" (p. 364).

In his concluding chapter, Fakhry analyzes the thought of, among others, the Egyptian scholar Sayyid Qutb, for whom the "roots of the decline of Western civilization are not material or economic but rather spiritual or moral; the West has lost the 'stock of values' that enabled it in the past to be the leader of mankind" (p. 381). Islamist groups have invested great importance in the ideas of such thinkers; this analysis is, therefore, a welcome addition to the text.

In Fakhry's hands, the complex ideas of the major Islamic philosophers and schools are made accessible to a wide audience without being unnecessarily simplified. His publishers should be assured that there will be a fourth, and no doubt, a fifth edition of A History of Islamic Philosophy produced in the future. 